\title{
Evaluation of Student Teachers Grouped According to Teaching Subjects: Students' Perception
}

\author{
Richard Tuimur $^{1}$, Elizabeth Role ${ }^{1} \&$ Lazarus Ndiku Makewa ${ }^{1, *}$ \\ ${ }^{1}$ University of Eastern Africa, Baraton, P.O. Box 2500, Eldoret, Kenya \\ * Corresponding author: University of Eastern Africa, Baraton, P.O. Box 2500, Eldoret, \\ Kenya. E-mail: ndikul@gmail.com
}

Received: October 2, 2012 Accepted: November 26, 2012 Published: December 16, 2012

doi:10.5296/ije.v4i4.2491ＵRL: http://dx.doi.org/10.5296/ije.v4i4.2491

\begin{abstract}
The purpose of this paper was to test if there was a significant difference between students' evaluation of their student teachers grouped according to teaching subjects. It also tested if there was a significant difference between evaluation of student teachers grouped according to teaching subjects in the following areas: preparation, supervision, teaching environment, and teaching practice experience. To test the hypotheses, Pearson's product measurement correlation coefficient and t-test were applied. The results indicate that the mean in the student evaluation of arts and sciences student teachers are significantly different. The results also suggest that there was no statistical significant difference between evaluation of the student teachers grouped according to teaching subjects (arts and sciences) on all the areas of teaching practice. Both groups have a high evaluation of preparation, teaching environment and teaching practice experience and have average evaluation on supervision.
\end{abstract}

Keywords: evaluation; student teachers; teaching subjects; teaching practice; supervision; preparation; Kenya 


\section{Introduction}

This study was conducted between January and March 2012. Its purpose was to test if there was a significant difference between students' evaluation of their University of Eastern Africa, Baraton (UEAB) student teachers grouped according to teaching subjects. It also tested if there was a significant difference between evaluation of student teachers grouped according to teaching subjects in the following areas: preparation, supervision, teaching environment, and teaching practice experience.

Teaching practice occupies a key position in the program of teacher education. It is a culminating experience in teacher preparation. It provides opportunity to beginning teachers to become socialized into the profession. Performance during teaching practice provides some basis for predicting the future success of the teacher. Outgoing popularity and centrality of teaching practice is an important contributing factor towards the quality of teacher education program. During teaching practice, working with students in schools provides a high degree of emotional involvement of a mostly positive nature. Student teachers grow through experience and they begin to link to a culture of teaching. During teaching practice, they feel engaged, challenged and empowered (Furlong et al, 1988). Approximately 1500 research papers dealing with different aspects of teacher education are published and indexed in ERIC (the Educational Resource Information Center) each year (Krull, 2005). These scholarly papers extend from international comparative studies of teacher preparation traditions and qualification requirements in the light of students' achievements ( Losito and Mintrop 2001), to the studies of teacher personal learning and development of professional characteristics (e.g. Berliner 1994, Bond et al 2000, etc).

Different countries have over the years developed their teaching practice programs to suit their divergent needs. Teaching practicum is a central element in most pre- service teacher education programs in New Zealand. After completing a degree in relevant content areas, prospective high school teachers in New Zealand typically enroll in a one year diploma at a college of Education. The year is intensive and a critical component is supervised teaching within selected high schools. The student teacher is attached to an experienced teacher, an associate teacher, who accepts responsibility for the day to day supervision of the student teacher's teaching experience. During each attachment, a visiting lecturer for the college of Education also observes the student teaching. However, the assessment of students' competence during practicum remains problematic (Liddicoat, et.al, 2003). In Australia, all teacher education programs at the University of Sydney require an internship of at least ten weeks. This occurs at the end of the program, at a stage in their professional development, when students do not require close supervision in the classroom (Liddicoat, et.al, 2003).

Rowe (2010), says that much of what is commonly claimed as 'effective teaching ' and implemented during the early and middle years of schooling in Australian schools, for either mainstream students or for those experiencing learning difficulties, is not grounded in findings from evidence-based research. In Singapore, the National Institute of Education believes that the Practicum enables student teachers to acquire beginning teaching competencies and is a core component of the Initial Teacher Preparation in NIE. The purpose of the practicum is to 
help prepare student teachers for the realities of student teaching by providing them with clear understanding of the contexts for schooling.

Different teacher training programs are being offered in Pakistan. In all the programs, teaching practice is a compulsory component except at M.Ed (Master of Education). In true spirit we can produce good teachers through this activity, but the procedure adopted in Pakistan is just to pass / kill time. Teaching practice duration is very short; it is about 4 to 8 weeks or teaching of 60 to 75 lessons. During teaching practice, student teachers are bound to the classrooms for teaching. They are not trained for the other activities performed in schools (Akbar, 2002). In South Africa, Practicum periods are described as 'work-based experience' and on-site induction into situated contexts of practice. No specific minimum time period is specified, but students are expected to be exposed to a variety of contexts during their teacher education program and the practicum constitutes 120 credit points out of a total of 480 for the program (effectively $25 \%$ ), which seems to indicate the importance afforded to the practicum in teacher education. In Kenya, just like many other countries, TP is considered to be very important in Teacher Education. It is said to be a means of transforming what student teachers have learnt in TE programs at university into an ability to actually teach in real classrooms (Barasa, 2005). Teaching Practice is the most important aspect of training an individual to become a professionally qualified teacher (Ayot \& Wanga, 1987).

Teaching Practice at UEAB is done in the fourth year of the course during the first term of the schools' calendar. Student teachers are placed to various high schools that are accessible and secure to the students and it runs for 12 weeks. UEAB bulletin (2008-2010) gives the graduation requirements for Bachelor of Education course to include 10 credits of teaching practice for 12 to 13 weeks depending on the length of the school term.

\section{Theoretical Framework}

This study was guided by the activity theory. This is a theoretical framework that has been used increasingly to investigate the world of professional development (Cook et al., 2002; Engeström, 1999; Grossman et al., 1999; Grossman et al., 1993; Roth and Tobin, 2002; Spillane et al., 2001; Spillane, et al., 1999). Activity theory is an outgrowth of the work of Soviet psychologist, Vygotsky and his colleague, Leont'ev (Engeström and Miettinen, 1999; Leont'ev, 1978). This theory is based on the premise that 'human activity is endlessly multifaceted, mobile, and rich in variation of content and form' (Engeström, 1999: 20). It is an 'interactive web of actors, artifacts, and the situation' (Spillane, 2001: 23) which can best be understood through a unit of analysis that allows that activity to be viewed from where it takes place. In the case of this study, this means viewing teaching practice during student teachers' placement in secondary schools.

Activity theory 'considers actions as events in a collective activity system' (Engeström, 1999: 30). The focal point of this model is the object, as it is the object that connects the actions to the activity. Engeström (1999: 31) proposed that it is the 'projection from the object to the outcome that . . . functions as the motive' for the activity and gives deeper 
meaning to the actions. In the case of student teachers on teaching practice, the object or goal may be to become effective teachers. Within activity theory, the analysis considers the activity of the actor (subject) as a task is performed toward meeting the object and the outcome.

The interactions with the tools (meditating artifacts), the rules, the community, and the division of tasks are also considered in the analysis (Engeström and Miettinen, 1999). The theory also views and analyzes a problem from the viewpoint of the subjects and the system. Engeström and Miettinen (1999: 10) suggested that the researcher 'constructs the activity system as if looking at it from above'. This relates to Bronfenbrenner (2000), who noted that development must be examined in context and is therefore dependent upon both the developing individual as well as the environment in which development is taking place. Individuals are both producers and products of their environment in that the individual influences and is influenced by the environment. The environment is depicted as a series of interlocking systems, each of which can impact the other.

Bannon (1997) noted that a professional development activity could not exist as an isolated entity. An activity is undertaken by a human agent (subject) who is motivated toward the solution of a problem or purpose (object), and mediated by tools (artifacts) in collaboration with others (community). The structure of the activity may be constrained by cultural factors including conventions (rules) and social strata (division of tasks) (Engeström, 1987). Engeström (1987) calls attention to the mediational role of the community and that of social structures including the division of tasks and established procedures. Bannon (1997) states that activity theory's emphasis on social factors and on interaction between agents and their environments explain why the principle of mediation plays a central role in the framework.

Reflected in this socio-cultural activity theory are Lave and Wenger's (1991) model of situated learning, which suggests that all learning should be understood as a process of participation in communities of practice. According to Lave and Wenger, learning occurs through apprenticing with others who are already part of a particular community or culture. In this manner, models of teacher education should be based on the premise that student teachers need to address and solve problems within the context in which they occur-the field experience (Alley et al., 1997). The facilitation of student teacher learning thus has to do with understanding and providing a field experience.

There is need to justify the selection of activity theory as the theoretical framework in this study. Activity theory has been praised for having the potential of illuminating how prospective teachers' trajectories through a series of settings can mediate their beliefs about teaching and consequently their practice (Grossman et al., 1999). Their study noted that 'activity theory can help account for changes in teachers' thinking and practice, even when those changes differ from one case to another case' (p. 4). This is important because it helps to explain that different individuals develop in particular ways when learning a professional activity even though they may undergo similar professional programs.

Activity theory's emphasis on the settings in which development takes place 
distinguishes it from theoretical perspectives that assume that teaching is a solitary profession (Grossman et al., 1999; McLaughlin and Talbert, 1993). It focuses on the social and cultural factors that influence development in particular contexts. In this way, it offers an understanding of how particular teaching practice settings shape and guide prospective teachers toward particular beliefs and practices about teaching. This is important in this study because student teachers were sent to different school settings and, inevitably, they were exposed to different conditions in their experiences of teaching practice.

The developmental focus of activity theory makes it a powerful framework for exploring components of professional development, particularly in studies that follow prospective teachers as they progress through different social contexts. Studies that focus on settings for professional development can reveal the kinds of social structures that promote the appropriation of tools that in turn result in particular kinds of teaching. An activity theory perspective allows an analysis of the consequences of different approaches to professional development, including university programs, school-based activities, and other structures with particular goals and practices (Bullough, 1989). This is useful for exploring the roles that settings and orientations contribute towards professional development of student teachers on teaching practice.

As noted from the preceding discussions, activity theory provides a rich theoretical basis for the importance of field experiences. According to Grossman et al., (1999) all too often research on teacher education has polarized the university and school settings and bemoaned the university's lack of influence. Student teachers cannot learn to teach without engaging in the activity of teaching practice in school settings. From this perspective, the design of field teaching practice is absolutely critical to the enterprise of teaching. Activity theory allows researchers to look at the ways in which student teachers grapple with college system and secondary school system in developing as teachers. This is significant for this study in understanding the relationships between college and schools during teaching practice and assessing the roles that schools and colleges ought to play.

Teaching practice is seen as a learning activity involving the process of social participation whereby the impact of the situation is fundamental. Lave and Wenger (1991) noted that the mastery of knowledge and skill requires student teachers or novices to move toward full participation in the socio-cultural practices of a community. Learning involves not only reflection upon and drawing implications from previous experiences but is immersed in and with the experience. Legitimate peripheral participation (Lave and Wenger, 1991) concerns the process by which student teachers may move toward full participation in the socio-cultural practices of a school system. The possibilities for learning are defined by the social structure of the community in the school system, and these can be explored through activity theory which puts the learning situation at the center of the study since it is the main "object" of teaching practice. 


\section{Literature Review}

\subsection{Teaching Practice}

A number of terms such as the teaching practice, student teaching, field studies, infield experience, school based experience or internship are used to refer to this activity (Taneja, 2000). The term teaching practice embraces all the learning experiences of student teachers in schools (Ashraf, 1999). The term teaching practice has three major connotations: the practice of teaching skills and acquisition of the role of a teacher; the whole range of experiences that students go through in schools; and the practical aspects of the course as distinct from theoretical studies (Stones \&Morris, 1977). Teaching practice is the name of the preparation of student teachers for teaching by practical training. It is the practical use of teaching methods, teaching strategies, teaching principles, teaching techniques and practical training and practice of different activities of daily school life.

Many institutions offering Initial Teacher Education (ITE) programmes require their students to take part in a field experience, in a school or a college or any other teaching institution where they can interact with an actual school community. This session is usually referred to as teaching practicum or teaching practice (Derrick \& Dicks, 2005; Brown \& Nachino-Brown, 1990; Richards, 1998; Ayot \& Wanga, 1987; Stones \& Morris, 1972). Currently, there is a general understanding among teacher educators that TP is a session for continued teacher learning; that it may help student teachers to reflect upon their subject matter, pedagogy, learners, curriculum, contexts and educational policies, with a view to improving their attitudes, knowledge and skills (Darling-Hammond, 2006; Imig \& Imig, 2006; Otero, 2006; Richards,1998; Bodóczsky \& Malderez, 1996). Adams et al. (2006) observe that "in moving to the front of the classroom, beginning teachers should reflectively critique their own school experiences and resulting beliefs about education" (p.1).

\subsection{Importance of Teaching Practice}

The 'professionalization' of teaching practice in higher education is becoming more important as universities try to respond to an increasingly diverse and discerning student population, issues relating to standards and quality, growing international competition, and generally 'doing more with less'. Exploratory studies suggest that discipline and teaching conceptualization have the strongest influence on teaching scholarship, while qualification and years of teaching have a moderate impact, and gender and post do not appear to play a significant part (Lueddeke, 2003). Teachers have a powerful, long- lasting influence on their students. They directly affect how students learn, what they learn, how much they learn, and the ways they interact with one another and the world around them. Considering the degree of the teacher's influence, it is important to understand what teachers should do to promote positive results in the lives of students - with regard to school achievement, positive attitude towards school, interest in learning, and other desirable outcomes. This understanding should be based both on what experts and stakeholders think teachers should do and on what educational research has shown to be significant in the preparation and practice of effective teachers (Stronge, 2002). 
Darling Hammond (2006b) identifies sustained TP as one of the 'pedagogical cornerstones' of 'powerful teacher education' (p. 306), which enables teachers to bridge the theory-practice and gain deep insights on the unique differences, interests and needs of learners. Derrick and Dicks (2005) consider TP as a key element of all approved teacher education qualifications in the United Kingdom and other countries. Richard \& Crookes (1998) note that it is considered a "major opportunity for the student teacher to acquire the practical skills and knowledge needed to function as an effective language teacher" (p. 9). To illustrate this importance, Richards \& Crookes report that seventy five percent of Teacher Education (TE) programmes that they studied, from various parts of the world, had a TP component in various forms. It has also been noted that TP plays a role in education similar to internship or field attachment in other professions such as medicine, law, and engineering. For this reason, some scholars have referred to $\mathrm{TP}$ as a clinical experience (Darling-Hammond, 2006a; Derrick \& Dicks, 2006; Brown \& Nacino-Brown, 1990). Darling-Hammond (2006) argues that:

Just as medical educators believe physicians cannot properly apply the techniques of medicine without understanding how the human body works, teacher educators in these programs (that she studied) believe that without direct knowledge of how learning occurs, teachers have no benchmarks by which to evaluate teaching ideas or materials, construct learning opportunities or adapt their teaching when students do not respond to a particular approach. Ensuring that teachers understand who they are teaching and how they learn empowers teachers to organise their practice around the pursuit of learning rather than just covering the curriculum or getting through the book. (p.85)

Darling-Hammond (2006a) explains that for teachers to know their work, there is necessity or both coursework and teaching practice that could enable student teachers to study learner development in various domains. She adds that teachers also need to know the unique differences, interests and needs of learners. Student teachers also need to be educated on how to observe learners, in class and outside - perhaps during co-curricular activities to enable them pitch their teaching at the right level. The secondary school teachers who will handle older children, mostly adolescents especially need knowledge on related factors that influence learning at this stage such as peer influence, media and socio-cultural constructions of issues that are likely to be of interest and influence to learners. Also included in this learner knowledge is the entry behaviour of learners into the subject.

In Kenya, just like many other countries, $\mathrm{TP}$ is considered to be very important in Teacher Education. It is said to be a means of transforming what teachers have learnt in TE programmes at university into an ability to actually teach in real classrooms (Barasa, 2005). Teaching practice is the most important aspect of training an individual to become a professionally qualified teacher (Ayot \& Wanga, 1987).TP serves many purposes, some of which include: linking coursework and actual teaching, learning from expertise, constructing own ways of teaching, understanding the broader contexts of teaching, assessment of the TE institution and cultivating the skills of reflective teaching (Darling -Hammond, 2006a; Zeichner, 2006; Bodóczsky \& Malderez,1996; Brown \& Nacino-Brown, 1990; Ayot \& Wanga, 1987). 


\section{Method}

This study was an evaluation study whereby a description of a particular situation is given and then an evaluative judgment is done. The data collected was encoded and analyzed using the Predictive Analysis Software (PASW).To test the first hypothesis, Pearson's product measurement correlation coefficient was used. For the second hypothesis, t-test was applied.

\subsection{Sample and Sampling Techniques}

Purposive sampling technique was used to identify schools where student teachers of UEAB were undertaking their Teaching Practice. During the survey, twenty six (26) student teachers undertaking their TP at various schools within Nandi Central District, nineteen (19) females and seven (7) males participated. Each student teacher was assigned a collaborating teacher and each one was asked and agreed to respond to the questionnaire. A total of nine hundred and forty seven (947) students participated as respondents with two hundred and sixty nine (269) females and six hundred and seventy eight (678) males. Simple random sampling was used to identify the class which evaluated the student teachers. Upon finding out how many classes the student teacher was teaching, we cast lots in order to pick one of the classes to administer the questionnaire. Cluster sampling technique was used to select student respondents.

\subsection{Research Instruments}

The research instrument used in this study was the questionnaire. Four sets of questionnaires were constructed: one for the collaborating teachers, one for the head teachers, one for the students, one for the supervisors (department staff), and the other for the student teachers. The questionnaire was modeled on the four-point scale numbered as; 4 = Agree, 3 Tend to agree, 2 - Tend to disagree, 1 - Disagree. These points represented the level of agreement or disagreement by the respondent. To ensure reliability, a pilot study was conducted in three schools within Nandi South District, which had students on teaching practice; one boys' school, one girls' school and one mixed school. Cronbach's alpha reliability coefficient was computed. A reliability Coefficient of 0.60 was set as a cut- off point. The obtained Cronbach's alpha coefficient for each sub-scale of each questionnaire was as follows: Students' Questionnaire: Teaching Effectiveness - 0.866 Student Teachers' Questionnaire: Preparation - 0.624 (after one statement was deleted) Supervision -0.862 Teaching Environment - 0.609 (after one statement was deleted) Teaching Practice Experience -0.621 (after one statement was deleted).

\subsection{Data Gathering Procedures}

After obtaining the research permit from the National Council of Science and Technology, the researchers visited the schools with the questionnaires to be administered. The school principal was requested for permission to have audience with the student teachers, collaborating teachers and the students with a view to administering the questionnaires. The researchers went ahead and administered the questionnaires to the various respondents. On student teachers, the researchers sat with them and went through the questions together. We asked the student teachers to request the collaborating teacher who was known to him/her so 
that the researchers could administer their questionnaire. Thereafter, the student teacher accompanied the researchers to the class where the students' questionnaire would be administered. The researchers then went through the questions with the students and then gave them a few minutes to answer the questions. We guided the respondents accordingly. In cases where the students were occupied at the time, we guided the deputy principal on how it should be done. The questionnaires were collected the same day.

\section{Results and Discussion}

\subsection{Comparison of Students' Evaluation by Teaching Subjects}

The first hypothesis tested if there was a significant difference between the students' evaluation of student teachers grouped according to teaching subjects (arts and sciences)

$$
\begin{aligned}
& \mathrm{H}_{0}: \mu \text { ARTS }=\mu \text { SCIENCES } \\
& \mathrm{H}_{\mathrm{a}}: \mu \text { ARTS } \neq \mu \text { SCIENCES }
\end{aligned}
$$

Table 1: T-test - Group Statistics

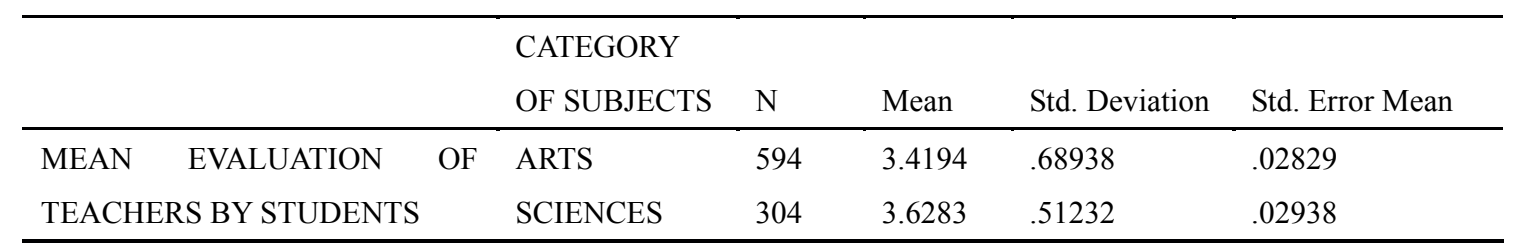

Out of a total of 898 students, 394 had an average mean of 3.4194 in arts while 304 students had an average mean of 3.6283 in sciences. To test for the statistical significance of this difference in student teachers grouped according to teaching subjects, an independent samples t-test was used as presented in table 2.

Table 2: T-test - Independent Samples Test

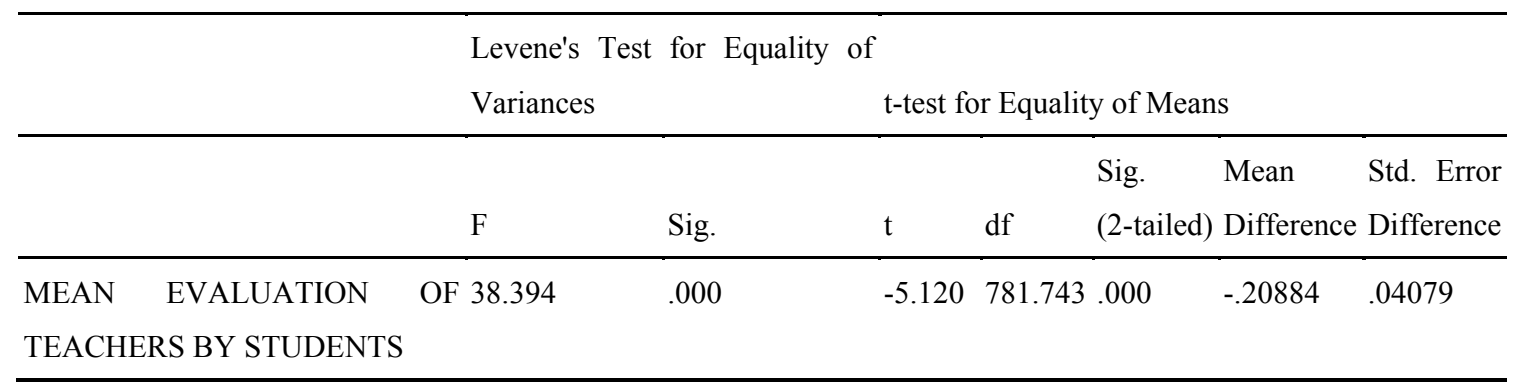

As it can be seen from table 2, the t-value is 5.120 with an associated p-value of 0.000 , which is less than 0.05 , hence we reject the null hypothesis above and conclude the mean difference in the student evaluation of arts and sciences student teachers are significantly different. This implies that the students agreed mostly in sciences that the student teachers exhibited a good performance and loosely tended to agree on arts subjects, implying that there is need to improve on arts subjects. 
The mode of teaching the arts subjects versus the science subjects varies significantly because the latter involves laboratory practical hence enabling the student teacher to interact with learners at individual basis. Science teachers also employ a variety of models and charts, which the learners find very captivating. Some of the science subjects are new to the learners as opposed to the arts which they were exposed to in primary school.

\subsection{Comparison of the Evaluation of Teaching Practice of Student Teachers by Teaching Subjects}

The second hypothesis tested if there was a significant difference between the evaluation of student teachers grouped according to teaching subjects (arts and sciences) of the following areas of teaching practice: a) preparation, b) supervision, c) teaching environment, and d) teaching practice experience.

Table 3 gives the descriptive statistics results for various areas of teaching.

Table 3: Test of Significance of Differences in Evaluation of student teachers grouped according to teaching subjects (arts and sciences) on areas of teaching practice

\begin{tabular}{llllllll}
\hline & CATEGORY & & & & \multicolumn{3}{c}{$\begin{array}{l}\text { Mean } \\
\text { Ranks }\end{array}$} \\
& OF & & & \multicolumn{2}{c}{$\begin{array}{l}\text { Mann- } \\
\text { Whalue }\end{array}$} \\
& SUBJECT & & & $\begin{array}{l}\text { Std. } \\
\text { Deviation }\end{array}$ & & U & \\
& TAUGHT & $\mathrm{N}$ & Mean & Dey & \\
\hline Preparation & ARTS & 21 & 3.7959 & .20113 & 13.48 & 52.00 & 0.973 \\
& SCIENCES & 5 & 3.8286 & .16444 & 13.60 & & \\
Supervision & ARTS & 21 & 3.0349 & .45442 & 13.52 & 52.00 & 0.974 \\
& SCIENCES & 5 & 3.0667 & .38586 & 13.40 & & \\
Teaching & ARTS & 21 & 3.5291 & .44984 & 13.79 & 46.50 & 0.693 \\
Environment & SCIENCES & 5 & 3.4444 & .45134 & 12.30 & & \\
Teaching & ARTS & 21 & 3.5397 & .38214 & 13.74 & 47.50 & 0.743 \\
Practice & SCIENCES & 5 & 3.4889 & .38968 & 12.50 & & \\
Experience & & & & & & & \\
\hline
\end{tabular}

The findings indicate that the 21 art student teachers have high regard for preparation (ARTS MEAN $=3.7959, \mathrm{SD}=0.20113$ and SCIENCES MEAN= 3.8286, $\mathrm{SD}=0.07354$ ), and low opinion in supervision (ARTS MEAN $=3.0349, \mathrm{SD}=0.45442$ and SCIENCES MEAN= $3.0667, \mathrm{SD}=0.38586$ ). The rest of the areas of teaching practice were fairly evaluated.

To test for the statistical significance of this difference in the evaluation of areas of teaching practice of student teachers grouped according to teaching subjects, Mann-Whitney $\mathrm{U}$ test was used. All the p-values associated with the test statistic $U$ are greater than 0.05 . Therefore, it is concluded that there is no significant difference between evaluation of the student teachers grouped according to teaching subjects (arts and sciences) on all the areas of teaching practice. Both groups have a high evaluation in preparation, teaching environment and teaching practice experience and have average evaluation of supervision.

On teaching practice experience, although the difference between the means is not 
statistically significant, the arts student teachers appear to have enjoyed a slightly better experience in the teaching practice with a mean rating of 3.5397 as compared to the science teachers who scored a mean rating of 3.4889. This may arise from the fact that art- based subjects are less strenuous in preparation and therefore they are likely to have more time to relax than their science counterparts.

In terms of the teaching environment, the arts student teachers also rated this numerically higher, though not statistically significant, than their science based colleagues with a mean rating of 3.5291 and 3.444, respectively. This further supports the fact that the art-based student teachers workload is lighter than the science-based teachers hence they are likely to have more time to enjoy their environment. It is also true that art-based teachers are more out-going and tend to adventure more than the science-based teachers who appear more engrossed with their tasks and have limited time for themselves.

On preparation, the science-based teachers had a slightly higher, although not statistically significant, mean rating of 3.8286 than their colleagues who have 3.7959 . This can be explained by the fact that science subjects have more activities which require intense work than the arts subjects. This will therefore require more in-put in preparation and organization of work, for example, practical work.

On supervision, the two subjects have a relatively close mean rating of 3.0667 and 3.0349 for science and arts respectively. We can therefore conclude that the supervision component of teaching practice is equally less favored by both sets of student teachers and therefore it is an area of concern. Despite this varied views by the student teachers, the supervisors who were interviewed do not seem to have an inclination towards any of the subjects. The department of Educational Administration, Curriculum and Teaching has made a good step of preparing the supervisors by organizing a conference before the teaching practice in order to harmonize their approach. The fact that they have employed a strategy of having at least two supervisors to see one student teacher at once leads to a balanced assessment and this is a laudable move by the department. The introduction of the Teaching Practice Committee, in the researcher's view, is a very good step because the teaching practice exercise is given the attention it deserves and their views and recommendations are likely to be taken more seriously than before.

\section{Conclusions and Recommendations}

The results show that students agreed that the student teachers who taught science subjects exhibited good performance and loosely tended to agree on arts subjects, implying that there was need to improve on arts subjects. The mode of teaching the arts subjects versus the science subjects vary significantly because the science subjects involve laboratory practical, thus enabling the student teachers to interact with learners on individual basis. Science teachers also employ a variety of models and charts which the learners find very captivating. Some of the science subjects are new to the learners as opposed to the arts which they were exposed to in primary school.

There was no statistical significant difference between evaluation of the student teachers 
grouped according to teaching subjects (arts and sciences) on all the areas of teaching practice. Both groups have a high evaluation of preparation, teaching environment and teaching practice experience and have average evaluation of supervision.

The findings of this study can help to develop and improve teacher education programs and pre-service teaching practices. Teacher education programs must be designed to bridge the gap between theory and practice and to better prepare these teachers. In order to enhance pre-service teachers' teaching efficacy, they are encouraged to observe and involve variety of arts and science experiences during their time in the field. It is no doubt that, field experiences provided the pre-service teacher a number of new experiences in the classroom. Hence, field experiences are needed to include efficient class preparation and effective teaching process. A better understanding of classroom evaluation, teaching environment and of pre-service teachers will facilitate the process of university level instruction.

This paper recommends that institutions who send students for teaching practice give them academic, moral and financial support. Future interventions should focus on how self-reflection and feedback affect teaching practice.

\section{References}

Adams, N. G. et al. (2006). Learning To Teach: A Critical Approach to Field Experiences. New Jersey: Lawrence Earlbaum Associates Inc. Publishers.

Akbar, R.A. (2002). A study Practice Teaching of Prospective Secondary School Teachers and Development of a Practice Teaching Model, Arid Agricultural University, Rawalpindi (Unpublished PhD Thesis).

Alley, R., Furtuwengler, C., \& Potthoff, D. (1997). 'Processes: Reflections and implications' in Byrd, D. \& Mcintre, D. (Ed). Research on the education of our nation's teachers. Thousand Oaks: Sage, 131-135.

Ashraf, M. (1990). Dictionary of Primary Education. A.P.H. Publishing Corporation, New Delhi.

Ayot, H.O., \& Wanga, P. E. (1987). Teaching Practice. Nairobi: Kenyatta University.

Bannon, L. (1997). Activity Theory. (22 January 2005).

Barasa, L. P. (2005). English Language Teaching in Kenya: Policy, Practice and Training. Eldoret: Moi University Press.

Berliner, D, (2001). Learning about and learning from teachers. International Journal of Educational Research, 35(1), 463-482.

Bodóczsky, C., \& Malderez, A. (1996). In Medgyes, P. and Malderez, A.(eds.) Changing Perspectives in Teacher Education. Oxford: Heinemann English Language Teaching, 58-74.

Bond, L, Smith, T, Baker, W.K, \& Hattie, J.A, (2000). The certification system of the national 
board for professional teaching standards: a construct and consequential validity study. Greensboro,NC: Center for Educational Research and Evaluation.

Bronfenbrenner, U. (2000). 'Ecological systems theory' in Kazdin, A. (ED.) Encyclopedia of psychology. Washington, DC and New York: American Psychological Association and Oxford University Press.

Brown, D. P., \& Nachino-Brown. (1990). Effective Teaching Practice: A guide for Student teachers and their supervisors. London: Stanley Thornes (Publishers) Ltd.

Bullough, R., Knowles, J., \& Crow, N. (1989). 'Teacher self-concept and student culture in the first year of teaching'. Teachers College Record, 91, 209-233.

Cook, L., Smagorinsky, P., Fry, P., Konopak, B., \& More, C., (2002). Problems in Developing a Constructivist Approach to Teaching: One Teacher's Transition from Teacher Preparation to Teaching. The Elementary School Journal, 102, 389-415.

Darling-Hammond, L. (2006 a). Powerful Teacher Education: Lessons from exemplary programmes. San Francisco: Jossey-Bass.

Darling-Hammond, L. (2006 b). Constructing 21st Century Teacher Education. Journal of Teacher Education, 57(3), 300-314. http://dx.doi.org/10.1177/0022487105285962

Derrick, J., \& Dicks, J. (2005). (eds.).Teaching Practice and Mentoring: The key to effective literacy, language and numeracy teacher training. Leicester: National Institute of Adult Continuing Education.

Engestrom, Y. (1987). Learning by Expanding. Helsinki: Orienta-Konsultit.

Engestrom, Y. (1999). 'Activity Theory and Transformation' in Engestrom, Y \& Punamaki, R. (Ed). Perspectives on Activity Theory. Cambridge: Cambridge University Press.

Engestrom, Y., \& Miettinen, R. (1999). 'Introduction'. In Engestrom, Y. Miettinen, R. \& Punamaki, R. (Ed). Perspectives on Activity Theory, Cambridge: Cambridge University Press.

Furlong,V.J., Hirst, P.U., \& Pilkington,K (1988). Initial Teacher Training and the Role of the School. Open University Press, Philadelphia.

Grossman, P., \& Stodolsky, S. (1994). 'Considerations of content and circumstances of secondary school teaching' in Darling-Hammond (Ed). Review of Research in Education. Washington DC: American Educational Research Association, 179-222.

Grossman, P., Smagorinsky, P., \& Valencia, S., (1999). Appropriating Conceptual and Pedagogical Tools for teaching English: A conceptual framework for studying professional development.

Imig, D. G., \& Imig, S. R. (2006). What Do Beginning Teachers Need To Know? An Essay. Journal of Teacher Education, 57(3), 286-291. http://dx.doi.org/10.1177/0022487105285964 
Krull, E. (2005). Theory and practice in today's teacher education, journal of the humanities and social sciences, 9(2), 123-129.

Lave, J., \& Wenger, E. (1991). Situated learning: legitimate peripheral participation. Cambridge: Cambridge University Press.

Leontev, A. (1978). Activity, Consciousness, and Personality. New York: Prentice-Hall.

Linder-Scholer, B. (1996). Industry's role in standards-based systemic reform, for K- 12 mathematics, science and technology education. A look at industry and community commitment to educational systemic reform. A handbook. College

Liston, D., \& Zeichner, K. (1991). Teacher Education and the Social Conditions of Schooling. New York: Routledge.

Losito, B., \& Mintrop, H. (2001). The teaching of civic education. In Citizenship and Education in twenty-eight countries, Civic knowledge and engagement at age fourteen, 157-173, J.Torney-Purta, R, Lehmann, H, Oswald, \& W, Shultz, eds. Amsterdam: IEA.

Lueddeke, G,R, (2003). Professionalizing Teaching Practice in Higher Education: a study of disciplinary variation and 'teaching-scholarship'. Studies in Higher Education, 28(2), 213-228.

Otero, V. K. (2006). Moving Beyond the "Get it or Don't Conception of Formative Assessment. Journal of Teacher Education, 57(3), 247-255. http://dx.doi.org/10.1177/0022487105285963

Richards, J. C. (1998). Beyond Training. Cambridge: Cambridge University Press.

Richards, J.C., \& Crookes, G. (1988). The Practicum in TESOL. TESOL Quarterly, 22(1), 9-27. http://dx.doi.org/10.2307/3587059

Roth, W., \& Tobin, K, (2002). 'Redesigning an urban teacher education program: An activity theory perspective'. Mind, Culture, and Activity, 9, 108-131.

Rowe, K, (2010). Effective Teaching Practices, Australian Council for Educational. Retrieved from http://www.acer.edu.au (April 27, 2012)

Spillane, J., Halverson, R., \& Diamond, J (1999). Toward A theory of Leadership Practice: A distributed Perspective. Retrieved from www.letus.org (15 December 2011)

Spillane, J., Halverson, R., \& Diamond, J (2001). Investigating School Leadership Practice: A distributed Perspective. Educational Researcher, 30, 28-30.

Stones, E., \& Morris, S. (1977). Teaching practice: Problems and perspectives: a reappraisal of the practical element in teaching preparation. London: Methuen.

Stronge, J.H. (2002). Qualities of effective teachers. Alexandria, VA: Association for Supervision and Curriculum Development.

Taneja, R.P. (2000). Encyclopaedia of Comparative Education, Vol.4. Ammol Publications 
Pvt. Ltd., New Delhi.

Trochim, W.M.K, (2006). Web Centre for Social Research. [Online] Available: http://www.socialresearchmethods.net (March 22, 2012)

UEAB. (2008/10). Bulletin, Eldoret.

Zeichner, K. (2006). Reflections of a University Based Teacher Educator on the future of College and University -based Teacher Education. Journal of Teacher Education, 57(3), 326- 340 .

\section{Copyright Disclaimer}

Copyright reserved by the author(s).

This article is an open-access article distributed under the terms and conditions of the Creative Commons Attribution license (http://creativecommons.org/licenses/by/3.0/). 